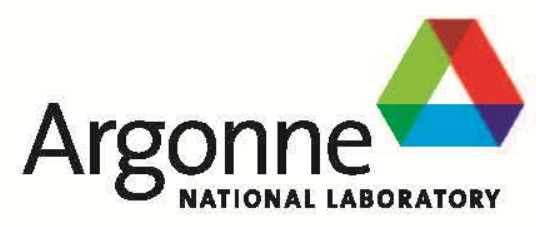

ANL/CSE-14/33

\title{
Optimization and Scale-up of Molybdenum-Recycle Process
}

Chemical Sciences and Engineering Division 


\begin{abstract}
About Argonne National Laboratory
Argonne is a U.S. Department of Energy laboratory managed by UChicago Argonne, LLC under contract DE-AC02-06CH11357. The Laboratory's main facility is outside Chicago, at 9700 South Cass Avenue, Argonne, Illinois 60439. For information about Argonne

and its pioneering science and technology programs, see www.anl.gov.
\end{abstract}

\title{
DOCUMENT AVAILABILITY
}

Online Access: U.S. Department of Energy (DOE) reports produced after 1991 and a growing number of pre-1991 documents are available free via DOE's SciTech Connect (http://Www.osti.gov/scitech/).

Reports not in digital format may be purchased by the public from the National Technical Information Service (NTIS):

U.S. Department of Commerce

National Technical Information Service

5301 Shawnee Rd

Alexandria, VA 22312

unw.ntis.gov

Phone: (800) 553-NTIS (6847) or (703) 605-6000

Fax: (703) 605-6900

Email: orders@ntis.gov

Reports not in digital format are available to DOE and DOE contractors from the Office of Scientific and Technical Information (OST):

U.S. Department of Energy

Office of Scientific and Technical Information

P.O. Box 62

Oak Ridge, TN 37831-0062

unw.osti.gov

Phone: (865) 576-8401

Fax: (865) 576-5728

Email: reports@osti.gov

\section{Disclaimer}

This report was prepared as an account of work sponsored by an agency of the United States Government. Neither the United States Government nor any agency thereof, nor UChicago Argonne, LLC, nor any of their employees or officers, makes any warranty, express or implied, or assumes any legal liability or responsibility for the accuracy, completeness, or usefulness of any information, apparatus, product, or process disclosed, or represents that its use would not infringe privately owned rights. Reference herein to any specific commercial product, process, or service by trade name, trademark, manufacturer, or otherwise, does not necessarily constitute or imply its endorsement, recommendation, or favoring by the United States Government or any agency thereof. The views and opinions of document authors expressed herein do not necessarily state or reflect those of the United States Government or any agency thereof, Argonne National Laboratory, or UChicago Argonne, LLC. 


\section{Optimization and Scale-up of Molybdenum-Recycle Process}

by

Peter Tkac and George F. Vandegrift

Chemical Sciences and Engineering Division, Argonne National Laboratory

prepared for

U.S. Department of Energy, National Nuclear Security Administration, Office of Defense Nuclear Nonproliferation

September 2014 



\section{CONTENTS}

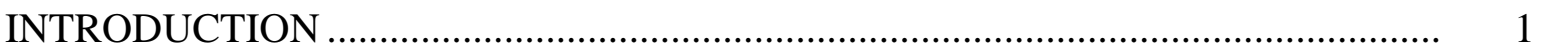

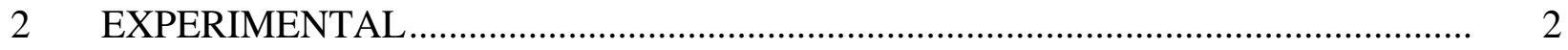

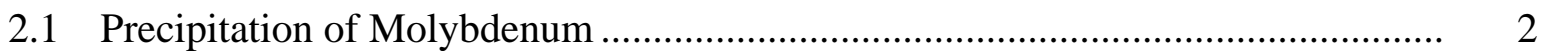

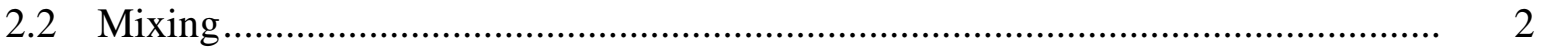

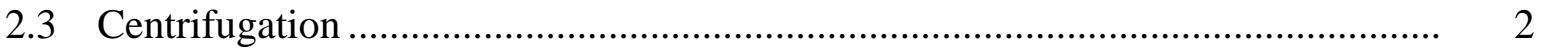

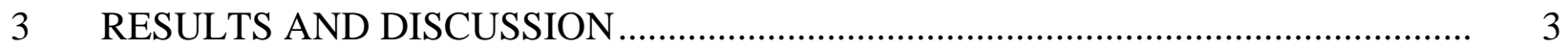

3.1 Small-Scale Experiments .............................................................................. 3

3.2 Large-Scale Experiments ............................................................................ 6

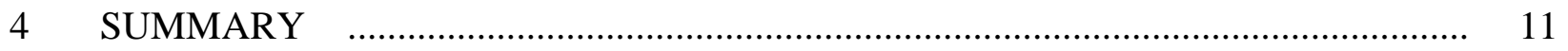

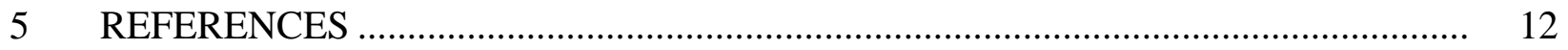

\section{TABLES}

1 Mo Yields and K Concentrations in the Recovered Mo Material

2 Concentrations of Various Elements in Starting Solutions and Recovered Mo

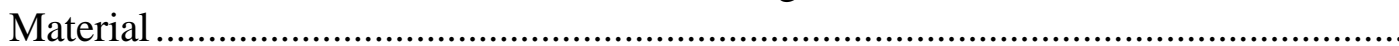

3 Experimental Data on the Effectiveness of AcA and $\mathrm{HNO}_{3}$ for Removal of

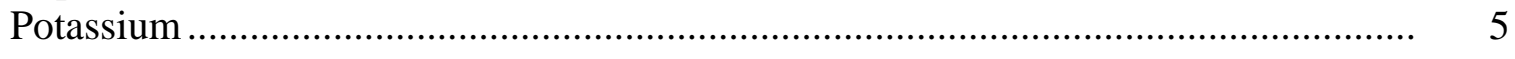

4 Effect of the Number of Washes with $\mathrm{HNO}_{3}$ and Mixing Time on Removal of Potassium from the Final $\mathrm{MoO}_{3}$ Product ........................................................... 7

5 Mo and K Concentrations in the Starting Solution and Recovered Mo Material for Large-Scale Experiment...................................................................................

6 Concentrations of Elements in the Starting Solution and Recovered Mo Material. ICP-MS data reported with 10\% uncertainty. 
This page intentionally left blank 


\section{OPTIMIZATION AND SCALE-UP OF MOLYBDENUM-RECYCLE PROCESS}

\section{INTRODUCTION}

Argonne National Laboratory (ANL), in cooperation with Oak Ridge National Laboratory (ORNL) and NorthStar Medical Technologies, LLC (NorthStar), is developing a recycling process for the solution containing valuable Mo-100 or Mo-98 enriched material from spent Mo-99/Tc-99m RadioGenix ${ }^{\mathrm{TM}}$ generators. The highly alkaline solution of $\mathrm{K}_{2} \mathrm{MoO}_{4}(0.2 \mathrm{~g}$ $\mathrm{Mo} / \mathrm{mL}$ in $5 \mathrm{M} \mathrm{KOH}$ ) from the spent RadioGenix ${ }^{\mathrm{TM}}$ generator contains about $1.8 \mathrm{~kg}$ of potassium per kilogram of molybdenum and recycling requirements for recovered Mo are $100 \mathrm{mg}$ of $\mathrm{K}$ per kilogram of Mo $(100 \mathrm{ppm})$. As part of the Mo recovery process, purification from several byproducts, such as $\mathrm{Zr}$ and $\mathrm{Nb}$, is necessary. The final product of the full recycle process is conversion to Mo metal powder. Due to the high cost of enriched Mo material, the required Mo recovery yield is $\sim 95 \%$. In this report we focus on the processing of highly alkaline $\mathrm{K}_{2} \mathrm{MoO}_{4}$ solution in $5 \mathrm{M} \mathrm{KOH}$, extraction of potassium, and conversion into $\mathrm{MoO}_{3}$ powder. Based on previous experiments [Tkac 2013], we used acetic acid to precipitate $\mathrm{Mo}$ as $\mathrm{MoO}_{3}$. The produced $\mathrm{MoO}_{3}$ powder is then sent to ORNL for further reduction to Mo metal and production of sintered Mo disks. 


\section{EXPERIMENTAL}

\subsection{PRECIPITATION OF MOLYBDENUM}

Precipitation of Mo was performed by adding glacial acetic acid (AcA) to a solution of $\mathrm{K}_{2} \mathrm{MoO}_{4}$ in $5 \mathrm{M} \mathrm{KOH}(0.2 \mathrm{~g}-\mathrm{Mo} / \mathrm{mL})$ with 5:1 volume ratio of acetic acid to $\mathrm{K}_{2} \mathrm{MoO}_{4}$ solution. The precipitation reaction is

$$
\mathrm{K}_{2} \mathrm{MoO}_{4}+2 \mathrm{KOH}+4 \mathrm{CH}_{3} \mathrm{COOH} \leftrightarrows \mathrm{MoO}_{3} \downarrow+4 \mathrm{CH}_{3} \mathrm{COOK}+3 \mathrm{H}_{2} \mathrm{O}
$$

The main advantage of using glacial AcA is that since it is a weak acid (equilibrium constant $\mathrm{K}_{\mathrm{a}}$ $=1.8 \times 10^{-5}$, where the $\mathrm{pH}$ of concentrated acid is $\sim 1.8$ ), the neutralization reaction is very mild. The Mo precipitate was then repeatedly washed with concentrated nitric acid. After precipitation of $\mathrm{MoO}_{3}$ with AcA, washing with $\mathrm{HNO}_{3}$, and centrifugation, a fine white precipitate that contains Mo began to form. This product could be due to the presence of soluble dimeric or polymeric species and will be discussed in more detail later. To eliminate Mo losses, we allowed samples after the precipitation step with acetic acid and the first $\mathrm{HNO}_{3}$ wash to sit for at least 24 hours.

After a final wash, the precipitate was re-dissolved and analyzed for $\mathrm{K}$ content using inductively coupled plasma mass spectrometry (ICP-MS) (PerkinElmer SCIEX ELAN DRC II). For largescale experiments, the $\mathrm{MoO}_{3}$ precipitate after the final wash was dried at $160^{\circ} \mathrm{C}$ and ground into powder. Then, an aliquot of $\mathrm{MoO}_{3}$ was dissolved in $\mathrm{NH}_{4} \mathrm{OH}$, acidified to a final concentration of $5 \mathrm{M} \mathrm{HCl}$, and submitted for ICP-MS analysis. Low potassium concentrations in the presence of high Mo concentrations can be determined after extracting Mo into 30\% tributyl phosphate (TBP) from $\sim 5 \mathrm{M} \mathrm{HCl}$ according to a procedure developed earlier [Tkac 2014a].

\subsection{MIXING}

For small-scale experiments using $\sim 1 \mathrm{~g}$ of Mo, samples were mixed in a vortex mixer. Large-scale experiments with $>40 \mathrm{~g}$ of Mo were performed with a Silverson L5M-A laboratory mixer at $7000 \mathrm{rpm}$.

\subsection{CENTRIFUGATION}

A Beckman centrifuge was used to separate the Mo precipitate from the acid. The samples were usually centrifuged at $3400 \mathrm{rcf}$ (relative centrifugal force) for 5-10 minutes. For large-scale experiments that required $2 \mathrm{~L}$ bottles, we used a Thermo Scientific centrifuge (Sorvall RC 12BP+) at 6200 rcf. 


\section{RESULTS AND DISCUSSION}

\subsection{SMALL-SCALE EXPERIMENTS}

Several experiments were performed when AcA was used to precipitate Mo from highly alkaline solutions and to wash the precipitate. Table 1 shows the results for the experiment with $60 \mathrm{~mL}$ of $\mathrm{K}_{2} \mathrm{MoO}_{4}$ in $5 \mathrm{M} \mathrm{KOH}$ (sample \#103 and \#104). About $300 \mathrm{~mL}$ of AcA was used to precipitate Mo and to perform two washing steps. Then, the Mo precipitate was washed 12 times with $\sim 280 \mathrm{~mL}$ of $70 \% \mathrm{HNO}_{3}$. We also performed small-scale experiment using $5 \mathrm{~mL}$ of $\mathrm{K}_{2} \mathrm{MoO}_{4}$ solution in $5 \mathrm{M} \mathrm{KOH}$ and addition of multiple elements ( $\mathrm{Li}, \mathrm{Be}, \mathrm{B}, \mathrm{Na}, \mathrm{Mg}, \mathrm{Al}, \mathrm{Si}, \mathrm{P}, \mathrm{Ca}, \mathrm{Ti}, \mathrm{V}$, Cr, Mn, Fe, Co, Ni, Cu, Zn, Ga, As, Rb, Sr, Zr, Nb, Ag, Cd, In, Sn, Sb, Cs, Ba, Hf, Ta, W, Re, $\mathrm{Hg}, \mathrm{Tl}, \mathrm{Pb}$ and $\mathrm{Bi}$ ) (\#105-106). After precipitation with $25 \mathrm{~mL}$ AcA, we performed two washing steps with $25 \mathrm{~mL}$ AcA and 12 washes with $25 \mathrm{~mL} \mathrm{HNO}_{3}$; samples were mixed for 2 minutes for each step and centrifuged. Potassium concentration was below $100 \mathrm{ppm}$ for all samples, and good Mo yields were observed, 93-100\%.

Table 2 shows the concentration of various elements in the starting solution and recovered Mo material for samples \#105 and \#106. The majority of elements were removed from the product, although the concentrations of $\mathrm{Ti}, \mathrm{V}, \mathrm{As}, \mathrm{Cd}, \mathrm{Sb}$, and $\mathrm{W}$ were above $25 \mathrm{ppm}$.

To optimize the recovery process, we investigated the effectiveness of both AcA and $\mathrm{HNO}_{3}$ for removal of potassium and Mo yield. Experimental data on the effectiveness of AcA and $\mathrm{HNO}_{3}$ as washing agents are presented in Table 3. If acetic acid is used to precipitate Mo, about $80 \%$ of the potassium is removed with $\sim 0.5 \%$ Mo losses. Although the precipitation reaction usually leads to formation of a Mo precipitate and a clear solution, over time a fine precipitate appears in the solution. This effect is most likely due to the formation of soluble polymeric Mo species that form at $\mathrm{pH} 4$ [Cotton 1988]:

$$
7 \mathrm{MoO}_{4}^{2-}+8 \mathrm{H}^{+}=\mathrm{Mo}_{7} \mathrm{O}_{24}^{5-}+4 \mathrm{H}_{2} \mathrm{O}
$$

TABLE 1 Mo Yields and K Concentrations in the Recovered Mo Material. ICP-MS data reported with $10 \%$ uncertainty.

\begin{tabular}{|c|c|c|c|c|c|}
\hline $\begin{array}{l}\text { Sample } \\
\text { No. }\end{array}$ & $\begin{array}{l}\mathrm{K}_{2} \mathrm{MoO}_{4} \text { in } 5 \\
\mathrm{M} \mathrm{KOH}, \mathrm{mL}\end{array}$ & $\begin{array}{c}\text { Precipitation } \\
+2 \text { washes } \\
\end{array}$ & $\mathrm{HNO}_{3}$ Washes & $\mathrm{K}, \mathrm{ppm}$ & $\begin{array}{c}\text { Mo yield, } \\
\%\end{array}$ \\
\hline 103 & 60 & $300 \mathrm{~mL}$ AcA & $12 \times 280 \mathrm{~mL} \mathrm{HNO}_{3}$ & 42.0 & 103 \\
\hline 104 & 60 & $300 \mathrm{~mL}$ AcA & $12 \times 280 \mathrm{~mL} \mathrm{HNO}_{3}$ & 39.7 & 94.9 \\
\hline 105 & 5 & 25 mL AcA & $12 \times 25 \mathrm{~mL} \mathrm{HNO}_{3}$ & 74.0 & 92.6 \\
\hline 106 & 5 & 25 mL AcA & $12 \times 25 \mathrm{~mL} \mathrm{HNO}_{3}$ & 59.6 & 94.8 \\
\hline
\end{tabular}


TABLE 2 Concentrations of Various Elements in Starting Solutions and Recovered Mo Material. ICP-MS data reported with 10\% uncertainty.

\begin{tabular}{|c|c|c|c|c|c|c|c|}
\hline \multirow[b]{2}{*}{ Element } & \multicolumn{7}{|c|}{ Content, ppm (mg of metal per kg-Mo) } \\
\hline & $\begin{array}{l}\text { Starting } \\
\text { Solution } \\
\end{array}$ & $\# 105$ & \#106 & Element & $\begin{array}{l}\text { Starting } \\
\text { Solution } \\
\end{array}$ & $\# 105$ & $\# 106$ \\
\hline $\mathrm{K}$ & $1,890,000$ & 74 & 60 & As & 49.4 & 71.3 & 67.7 \\
\hline $\mathrm{Li}$ & 38.0 & ND & ND & Se & ND & ND & ND \\
\hline $\mathrm{Be}$ & 44.8 & ND & ND & $\mathrm{Rb}$ & 118 & 1.30 & 1.90 \\
\hline B & 76.1 & 2.17 & 3.10 & $\mathrm{Sr}$ & 6.59 & 0.15 & 0.20 \\
\hline $\mathrm{Na}$ & 642 & 17.0 & 23.7 & $\mathrm{Zr}$ & 36.1 & 0.44 & 0.31 \\
\hline $\mathrm{Mg}$ & 28.5 & 12.5 & 19.9 & $\mathrm{Nb}$ & 27.1 & 17.0 & 20.8 \\
\hline $\mathrm{Al}$ & 85.8 & 9.03 & 10.4 & Ag & ND & ND & ND \\
\hline $\mathrm{Si}$ & 989 & ND & ND & Cd & 1660 & 1240 & 1290 \\
\hline $\mathrm{P}$ & ND & ND & ND & In & 29.5 & 0.77 & 0.73 \\
\hline $\mathrm{Ca}$ & ND & ND & ND & Sn & 54.7 & 2.30 & 1.67 \\
\hline $\mathrm{Ti}$ & 54.1 & 32.2 & 32.1 & $\mathrm{Sb}$ & 53.4 & 28.8 & 24.2 \\
\hline $\mathrm{V}$ & 58.0 & 81.6 & 91.0 & Cs & 54.3 & 4.53 & 4.89 \\
\hline $\mathrm{Cr}$ & 25.7 & ND & ND & $\mathrm{Ba}$ & 3.64 & 3.70 & 3.96 \\
\hline $\mathrm{Mn}$ & 1.77 & 0.37 & 0.77 & Hf & 43.3 & 0.42 & 0.33 \\
\hline $\mathrm{Fe}$ & ND & ND & ND & Ta & 17.8 & 21.0 & 21.6 \\
\hline Co & 1.20 & ND & ND & W & 165 & 153 & 152 \\
\hline $\mathrm{Ni}$ & ND & ND & ND & $\mathrm{Re}$ & 49.5 & 0.51 & 0.84 \\
\hline $\mathrm{Cu}$ & 59.7 & 2.49 & 11.4 & $\mathrm{Hg}$ & 7.10 & 2.88 & 2.98 \\
\hline $\mathrm{Zn}$ & 83.5 & ND & 12.4 & $\mathrm{Tl}$ & 41.0 & 2.43 & 2.32 \\
\hline $\mathrm{Ga}$ & 48.2 & ND & ND & $\mathrm{Pb}$ & 49.3 & 0.59 & 1.15 \\
\hline $\mathrm{Ge}$ & 52.9 & 3.46 & ND & $\mathrm{Bi}$ & 28.0 & 0.42 & 0.14 \\
\hline
\end{tabular}

ND - not detected.

Equilibria may then also be established for the following reaction:

$$
\mathrm{Mo}_{7} \mathrm{O}_{24}^{6-}+\mathrm{H}^{+}=\mathrm{HMo}_{7} \mathrm{O}_{24}^{5-}
$$

and

$$
\mathrm{HMo}_{7} \mathrm{O}_{24}^{5-}+\mathrm{H}^{+}=\mathrm{H}_{2} \mathrm{Mo}_{7} \mathrm{O}_{24}^{4-}
$$

Additional isopolyanionic forms of molybdenum may develop via the reaction:

$$
\mathrm{Mo}_{7} \mathrm{O}_{24}^{6-}+3 \mathrm{H}^{+}+\mathrm{HMoO}_{4}^{-}=\mathrm{Mo}_{8} \mathrm{O}_{26}^{4-}+2 \mathrm{H}_{2} \mathrm{O}
$$

These species probably decompose over time to hydrated $\mathrm{MoO}_{3}$ and form the fine precipitate. Therefore, sufficient time is required for this conversion to keep the Mo recovery as high as possible. 
TABLE 3 Experimental Data on the Effectiveness of AcA and $\mathrm{HNO}_{3}$ for Removal of Potassium. Data are reported with $10 \%$ uncertainty.

\begin{tabular}{|c|c|c|c|c|c|}
\hline Step & $\begin{array}{c}\begin{array}{c}\text { Volume, } \\
\mathrm{mL}\end{array} \\
\end{array}$ & Reagent & $\begin{array}{c}\text { K removed, } \\
\%\end{array}$ & Mo, \% & $\begin{array}{c}\text { mg of } \mathrm{K} / \mathrm{kg} \\
\text { of Mo }\end{array}$ \\
\hline Precipitation & 25 & 17.4 M AcA & 80.0 & 0.47 & \\
\hline Wash \#1 & 25 & 17.4 M AcA & 8.8 & 0.10 & \\
\hline Wash \#2 & 25 & 17.4 M AcA & 2.3 & 0.18 & \\
\hline Wash \#3 & 25 & $\begin{array}{l}15.9 \mathrm{M} \\
\mathrm{HNO}_{3}\end{array}$ & 13.7 & 0.75 & \\
\hline Wash \#4 & 25 & $\begin{array}{c}15.9 \mathrm{M} \\
\mathrm{HNO}_{3}\end{array}$ & 3.3 & 0.35 & \\
\hline \#111 & & Product* & $1.05 \%$ & $95.15 \%$ & 20219 \\
\hline Precipitation & 25 & 17.4 M AcA & 78.1 & 0.48 & \\
\hline Wash \#1 & 25 & 17.4 M AcA & 7.4 & 0.11 & \\
\hline Wash \#2 & 25 & $\begin{array}{l}15.9 \mathrm{M} \\
\mathrm{HNO}_{3}\end{array}$ & 15.6 & 1.22 & \\
\hline Wash \#3 & 25 & $\begin{array}{l}15.9 \mathrm{M} \\
\mathrm{HNO}_{3}\end{array}$ & 3.9 & 0.58 & \\
\hline Wash \#4 & 25 & $\begin{array}{c}15.9 \mathrm{M} \\
\mathrm{HNO}_{3}\end{array}$ & 0.9 & 0.31 & \\
\hline \#112 & & Product* & $0.50 \%$ & $96.86 \%$ & 9403 \\
\hline Precipitation & 25 & 17.4 M AcA & 81.5 & 0.59 & \\
\hline Wash \#1 & 25 & $\begin{array}{l}15.9 \mathrm{M} \\
\mathrm{HNO}_{3}\end{array}$ & 23.4 & 1.25 & \\
\hline Wash \#2 & 25 & $\begin{array}{l}15.9 \mathrm{M} \\
\mathrm{HNO}_{3}\end{array}$ & 3.0 & 0.25 & \\
\hline Wash \#3 & 25 & $\begin{array}{l}15.9 \mathrm{M} \\
\mathrm{HNO}_{3}\end{array}$ & 0.6 & 0.19 & \\
\hline Wash \#4 & 25 & $\begin{array}{l}15.9 \mathrm{M} \\
\mathrm{HNO}_{3}\end{array}$ & 0.2 & 0.18 & \\
\hline \#113 & & Product* & $0.14 \%$ & $96.48 \%$ & 2703.1 \\
\hline Precipitation & 25 & $\begin{array}{l}15.9 \mathrm{M} \\
\mathrm{HNO}_{3}\end{array}$ & 84.9 & 5.44 & \\
\hline Wash \#1 & 25 & $\begin{array}{l}15.9 \mathrm{M} \\
\mathrm{HNO}_{3}\end{array}$ & 11.2 & 0.46 & \\
\hline Wash \#2 & 25 & $\begin{array}{l}15.9 \mathrm{M} \\
\mathrm{HNO}_{3}\end{array}$ & 1.4 & 0.25 & \\
\hline Wash \#3 & 25 & $\begin{array}{l}15.9 \mathrm{M} \\
\mathrm{HNO}_{3}\end{array}$ & 0.2 & 0.32 & \\
\hline Wash \#4 & 25 & $\begin{array}{l}15.9 \mathrm{M} \\
\mathrm{HNO}_{3}\end{array}$ & 0.04 & 0.40 & \\
\hline \#114 & & Product* & $0.017 \%$ & $91.96 \%$ & 347.3 \\
\hline
\end{tabular}

*Percentages of $\mathrm{K}$ and Mo in final product. 
When $\mathrm{HNO}_{3}$ is used to precipitate Mo, the Mo losses in the first precipitation step are significantly higher than those when acetic acid is used (5.44\% vs. about $0.5 \%)$. Results also clearly show that nitric acid is more proficient in removing potassium, and the sooner the AcA is replaced by $\mathrm{HNO}_{3}$ to wash the Mo precipitate, the more effective is the removal of potassium. The formation of fine precipitate is most likely due to the presence of a soluble dimeric species, $\mathrm{H}_{2} \mathrm{Mo}_{2} \mathrm{O}_{6}^{2+}$ [Esbelin 2001], that temporarily forms through the protonation of molybdenum trioxide but then precipitates as Mo oxide [Tkac 2014b].

The data in Table 4 show the effectiveness of potassium removal when nitric acid washing is used after the precipitation of Mo with acetic acid. These small-scale experiments (Tables 3 and 4) showed that the best potassium removals and Mo recoveries are obtained when acetic acid is used to precipitate Mo, followed by washing the Mo precipitate with concentrated nitric acid. Additionally, prolonged mixing has a positive effect on removal of potassium in the final product, and better Mo purity can be achieved with the same number of washing steps. Molybdenum recoveries were in the range of $98-100 \%$.

It was also demonstrated that when recycled $\mathrm{MoO}_{3}$ material contains a high amount of potassium, further potassium removal can be accomplished by the reduction process. Recycled $\mathrm{MoO}_{3}$ powder containing $190 \mathrm{mg}-\mathrm{K} / \mathrm{kg}-\mathrm{Mo}$ was sent to ORNL for reduction and then analyzed for potassium. The concentration in the reduced Mo powder was $40 \mathrm{mg}-\mathrm{K} / \mathrm{kg}-\mathrm{Mo}$, indicating a decontamination factor of $\sim 4.8$.

We also investigated an option to recycle the nitric acid that is used in the washing steps to remove potassium from the Mo precipitate. Acetic acid that is used to precipitate Mo contains 60-70 g-K/L, and the first $\mathrm{HNO}_{3}$ wash contains $1.6 \mathrm{~g}-\mathrm{K} / \mathrm{L}$, but if the first $\mathrm{HNO}_{3}$ wash is disposed, the rest of the $\mathrm{HNO}_{3}$ fractions contain 100-200 mg-K/L. Combined nitric acid washes containing 165 ppm of potassium were distilled by rotary evaporation, and condensed (recycled) $\mathrm{HNO}_{3}$ was submitted for ICP-MS analysis to determine the potassium concentration. The potassium concentration in the recycled $\mathrm{HNO}_{3}$ was very low $(\sim 0.1 \mathrm{ppm})$, which could significantly reduce the volume of nitric acid waste. Recycled $\mathrm{HNO}_{3}$ containing $\sim 0.1 \mathrm{mg}-\mathrm{K} / \mathrm{L}$ could be used in the first 4-5 $\mathrm{HNO}_{3}$ washes.

\subsection{LARGE-SCALE EXPERIMENTS}

For large-scale experiments, a fresh solution of $\mathrm{K}_{2} \mathrm{MoO}_{4}$ in $5 \mathrm{M} \mathrm{KOH}$ was prepared and analyzed by ICP-MS to determine the starting Mo and K concentrations. Table 5 shows the concentrations of $\mathrm{K}$ and Mo in the starting solution and in the recovered Mo material. The 
TABLE 4 Effect of the Number of Washes with $\mathrm{HNO}_{3}$ and Mixing Time on Removal of Potassium from the Final $\mathrm{MoO}_{3}$ Product. Mo was precipitated using AcA

\begin{tabular}{|c|c|c|c|c|c|}
\hline \multirow[b]{2}{*}{ Sample } & \multirow[b]{2}{*}{$\begin{array}{l}\text { Mixing } \\
\text { time, min }\end{array}$} & \multirow[b]{2}{*}{$\begin{array}{c}\text { No. } \mathrm{HNO}_{3} \\
\text { washes }\end{array}$} & \multicolumn{3}{|c|}{ Product Content } \\
\hline & & & $\begin{array}{c}\text { K Removed, } \\
\%\end{array}$ & Mo, \% & $\begin{array}{c}\mathrm{mg} \text { of } \mathrm{K} / \mathrm{kg} \\
\text { of Mo }\end{array}$ \\
\hline \#115 & 4 & 6 & 99.956 & 98.1 & 777.3 \\
\hline \#116 & 4 & 8 & 99.985 & 99.5 & 261.2 \\
\hline \#117 & 4 & 10 & 99.992 & 99.4 & 142.7 \\
\hline \#118 & 4 & 12 & 99.996 & 96.7 & 71.6 \\
\hline$\# 120$ & 10 & 12 & 99.999 & $\sim 100$ & 14.7 \\
\hline \#121 & 10 & 14 & 99.999 & $\sim 100$ & 10.8 \\
\hline
\end{tabular}


TABLE 5 Mo and K Concentrations in the Starting Solution and Recovered Mo Material for Large-Scale Experiment $^{\mathbf{a}}$

\begin{tabular}{|c|c|c|c|c|c|c|c|c|c|}
\hline Sample \# & $\begin{array}{c}\text { Start Mo } \\
\text { Solution, g }\end{array}$ & Mo, M & $\begin{array}{c}\text { Total Start } \\
\text { Mo, g }\end{array}$ & $\begin{array}{c}\text { Total Start } \\
\text { K, g }\end{array}$ & $\begin{array}{c}\mathrm{MoO}_{3} \\
\text { Product, g }\end{array}$ & $\begin{array}{c}\text { Mo } \\
\text { Product, g }\end{array}$ & $\begin{array}{l}\text { K Product, } \\
\text { mg }\end{array}$ & $\begin{array}{c}\text { Mo } \\
\text { Yield, \% }\end{array}$ & $\mathrm{K}, \mathrm{ppm}$ \\
\hline 125 & 515 & 2.06 & 65.8 & 117.1 & 87.0 & 55.2 & 6.53 & 83.9 & 118.3 \\
\hline 126 & 515 & $\begin{array}{c}\mathrm{KOH}, \mathrm{M} \\
4.87 \\
\mathrm{Mo}, \mathrm{g} / \mathrm{mL} \\
0.198\end{array}$ & 65.8 & 117.1 & 89.3 & 57.4 & 7.84 & 87.2 & 136.6 \\
\hline Whole batch & 1030 & & 131.5 & 234.1 & 176.3 & 112.6 & 14.4 & 85.6 & 127.6 \\
\hline
\end{tabular}

a ICP-MS data reported with 10\% uncertainty. K/Mo mole ratio: 4.37. A volume of 3.2 L of acetic acid was used to precipitate Mo, and $27 \mathrm{~L}$ of nitric acid was used in all washing steps. 
ICP-MS results from the large-scale Mo recovery process showed that after nine washes with nitric acid, 99.994\% of the potassium was removed, and its concentration in the final $\mathrm{MoO}_{3}$ product was $\sim 128 \mathrm{ppm}$.

Because of the difficulties with dispersing the Mo precipitate during the first and second nitric acid washes, the concentration of potassium in the final product was expected to be even higher, which indicates good mixing. The Mo recovery yield was $\sim 86 \%$. About $5 \%$ of the molybdenum was found in the acetic acid fraction, and the remaining portion was found in the nitric acid fraction.

Table 6 shows the data for the elemental concentrations in the starting solution and recovered $\mathrm{MoO}_{3}$ product. Besides $\mathrm{K}, \mathrm{Si}$, and $\mathrm{W}$, concentrations of all other elements in the final product were below $25 \mathrm{ppm}$. The starting solution had a high concentration of $\mathrm{Si}$, which was most likely leached out from the glass volumetric flask during solution preparation. To avoid the introduction of $\mathrm{Si}$ into the starting solution, $\mathrm{K}_{2} \mathrm{MoO}_{4}$ should be prepared and stored in a nonglass container.

TABLE 6 Concentrations of Elements in the Starting Solution and Recovered Mo Material. ICP-MS data reported with $10 \%$ uncertainty.

\begin{tabular}{cccc}
\hline & & & \\
& \multicolumn{3}{c}{ Content, ppm (mg of metal per kg-Mo) } \\
\cline { 2 - 4 } & Starting Solution & $\# 125$ & $\# 126$ \\
\hline & & & \\
$\mathrm{K}$ & $1,780,000$ & 118 & 137 \\
$\mathrm{Si}$ & 1630 & 266 & 278 \\
$\mathrm{P}$ & $\mathrm{ND}^{\mathrm{a}}$ & $\mathrm{ND}$ & $\mathrm{ND}$ \\
$\mathrm{Cr}$ & $\mathrm{ND}$ & 10.5 & 14.7 \\
$\mathrm{Mn}$ & 2.97 & 1.24 & 1.13 \\
$\mathrm{Fe}$ & $\mathrm{ND}$ & $\mathrm{ND}$ & $\mathrm{ND}$ \\
$\mathrm{Ni}$ & $\mathrm{ND}$ & 3.35 & 1.86 \\
$\mathrm{Na}$ & $\mathrm{NA}$ & 23.9 & 18.5 \\
$\mathrm{Mg}$ & $\mathrm{NA}$ & 0.72 & 16.3 \\
$\mathrm{Al}$ & $\mathrm{NA}$ & 0.80 & 0.88 \\
$\mathrm{Ti}$ & $\mathrm{NA}$ & 4.75 & 4.58 \\
$\mathrm{Co}$ & $\mathrm{NA}$ & 0.02 & 0.01 \\
$\mathrm{Cu}$ & $\mathrm{NA}$ & 3.66 & 0.91 \\
$\mathrm{Zn}$ & $\mathrm{NA}$ & 3.57 & 0.93 \\
$\mathrm{Sn}$ & $\mathrm{NA}$ & 0.11 & 0.10 \\
$\mathrm{~W}$ & $\mathrm{NA}$ & 35.2 & 36.5 \\
\hline
\end{tabular}

a ND- not determined.

b NA- not analyzed. 
A portion of the recovered $\mathrm{MoO}_{3}$ powder was converted into ammonium molybdate $\left(\left(\mathrm{NH}_{4}\right)_{2} \mathrm{Mo}_{7} \mathrm{O}_{24}\right)$ by dissolving it in ammonium hydroxide. After air drying, both $\left(\mathrm{NH}_{4}\right)_{2} \mathrm{Mo}_{7} \mathrm{O}_{24}$ and $\mathrm{MoO}_{3}$ were sent to ORNL for reduction to Mo metal. The sample of $\mathrm{MoO}_{3}(\# 126)$ was reduced to Mo metal, pressed into sintered Mo disks that were dissolved in hydrogen peroxide, and analyzed for potassium with ICP-MS. The concentration of potassium in recycled Mo material was $98 \mathrm{ppm}$ (compared with $137 \mathrm{ppm}$ of $\mathrm{K}$ in the recycled $\mathrm{MoO}_{3}$ for sample \#126, Table 6). This result might indicate some removal of potassium during the reduction process, but as previously discussed, it differs significantly from the results for a small-scale recovered powder that showed a decrease in potassium concentration from $190 \mathrm{ppm}$ (recovered $\mathrm{MoO}_{3}$ ) to $40 \mathrm{ppm}$ (reduced Mo powder). As more samples of recycled $\mathrm{MoO}_{3}$ material are reduced to Mo metal, we should be able to determine the decontamination factor for $\mathrm{K}$ during the reduction process more precisely.

We also processed $\sim 4.5 \mathrm{~L}$ of $\mathrm{K}_{2} \mathrm{MoO}_{4}$ solution obtained after chemical processing of irradiated natural Mo targets in the University of Missouri Research Reactor. Molybdenum recovery yields were in the range of 93.4-95.8\%, bringing the total amount of recovered $\mathrm{MoO}_{3}$ powder to $\sim 1.24 \mathrm{~kg}$. Potassium concentrations in the final products were in the range of 41-213 ppm. Results are discussed in more detail in a separate report [Tkac 2014b]. 


\section{SUMMARY}

Small-scale experiments showed the most effective way of removing potassium from recovered $\mathrm{MoO}_{3}$ product is to use acetic acid in the precipitation step, followed by multiple $\mathrm{HNO}_{3}$ washes. It was demonstrated that the final concentration of potassium in the $\mathrm{MoO}_{3}$ product can be affected by mixing time and the number of $\mathrm{HNO}_{3}$ washes. Molybdenum recoveries near $100 \%$ were obtained for the small-scale experiments. Large-scale experiments showed good removal of potassium, although Mo recoveries were about $95 \%$ or less. 


\section{REFERENCES}

F. A. Cotton and G. Wilkinson, 1988, Advanced Inorganic Chemistry, New York, Wiley, 1988.

E. Esbelin, P. Gareil, M. Masson, and J. L. Emin, 2001, "Investigation of Mo(VI) MonomerDimer Equilibrium in Highly Acidic Solutions by UV Absorbance Spectroscopy Using Refined Numerical Processing,” Analytica Chimica Acta 433 (2001) 299-310.

P. Tkac and G. F. Vandegrift, 2014a, Method for Increased Accuracy of ICP-MS Detection of Potassium in Samples with High Molybdenum Content, Report ANL/CSE-14/16, January.

P. Tkac, G. F. Vandegrift, and J. Harvey, 2014b, Recovery of Mo from Natural Mo Targets Irradiated at MURR, Report ANL/CSE-14/25, September.

P. Tkac, G. F. Vandegrift, S. D. Nunn, and J. Harvey, 2013, Recovery of Mo for Accelerator

Production of Mo-99 Using $(\gamma, n)$ Reaction on Mo-100, Report ANL/CSE-13/45, September 30, 2013. 
This page intentionally left blank 



\section{Argonne}

Chemical Sciences and Engineering Division

Argonne National Laboratory

9700 South Cass Avenue, Bldg. 205

Argonne, IL 60439-4837

www.anl.gov

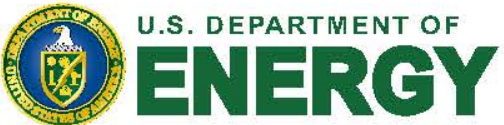

Argonne National Laboratory is a U.S. Department of Energy

laboratory managed by UChicago Argonne, LLC 